\title{
Arbuscular mycorrhizal inoculation of micropropagated strawberry and field observations in Finland
}

\author{
M Vestberg \\ Agricultural Research Centre of Finland, Laukaa Research and Elite Plant Unit, SF-41340 Laukaa, Finland
}

(COST Meeting, 21-23 May 1992, Dijon, France)

\begin{abstract}
Summary - Micropropagated plantlets of strawberry (Fragaria $x$ ananassa Duch Senga Sengana) were inoculated at the beginning of the weaning stage with a Glomus mosseae strain from Rothamsted Experimental Station (UK) or with 8 Finnish Glomus isolates, including $1 \mathrm{G}$ mosseae isolate, $4 \mathrm{G}$ intraradix isolates and 3 isolates of an unidentified Glomus species. After 8 wk (July 1990), inoculated plants were planted in the field: the most efficient fungi, ie $G$ mosseae Rothamsted, Glomus sp $\mathrm{V}_{3}$ and Glomus sp $\mathrm{V}_{4}$, increased shoot growth several-fold during the weaning stage. Growth responses persisted throughout the $1 \mathrm{st} \mathrm{yr}$ in the field, and partly throughout the $2 \mathrm{nd} \mathrm{yr}$. Root colonization by different fungi was from near $0-60 \%$ during the weaning stage. In the $2 n d y r$, after overwintering, root colonization of inoculated plants ranged from $8-35 \%$ as compared to $4 \%$ for the control plants. The need for more precise studies of the influence of winter on the biological efficiency of introduced VAM fungi to strawberry roots is discussed.
\end{abstract}

strawberry / arbuscular mycorrhizal fungi / microplant weaning stage

Résumé - Inoculation de mycorhizes arbusculaires à des fraisiers micropropagés et observation en champ en Finlande. Des plantes de fraisier. (Fragaria + ananassae Duch, Senga Sengana) ont été inoculées au début du sevrage avec une souche de Glomus mosseae provenant de Rothamsted Experiment Station, ou avec 1 des 8 isolats finnois de Glomus dont 1 de $\mathrm{G}$ mosseae 4 de $\mathrm{G}$ intraradix et 3 isolats d'une espèce non identifiée de Glomus. Après 8 semaines, en juillet 1990, les plantes inoculées ont été plantées au champ. Les champignons les plus efficaces, c'est-à-dire $\mathrm{G}$ mosseae Rothamsted, $\mathrm{G} s p, V_{3}$ et $\mathrm{G} s p V_{4}$ ont multiplié la croissance des tiges de plusieurs fois pendant la période de sevrage. La réponse de croissance persista pendant toute la première année au champ, et partiellement pendant la deuxième année. La colonisation des racines par les différents champignons a été de presque 0 à $60 \%$ pendant le sevrage. La deuxième année, après passage de l'hiver, la colonisation variait de 8 à $35 \%$, contre $4 \%$ pour les témoins. Le besoin d'études plus précises sur l'influence de l'hiver sur l'efficacité biologique des VAM introduites dans les racines de fraisier est discuté.

fraisier / champignon mycorhizien arbusculaire / microplant / sevrage

\section{INTRODUCTION}

Cultivated strawberry was originally claimed to benefit from arbuscular mycorrhizal (AM) inoculation only when soil phosphorus is limiting for plant growth (Holevas, 1966; Daft and Okusaya, 1973). Dunne and Fitter (1989), however, found that strawberry has a very high phosphorus demand, especially during the reproductive phase. They therefore concluded that the presence of a functional symbiosis can be important even under commercial cultural conditions with high fertilizer applications. The general use of microprop- agation for the production of elite stock of strawberry has opened up even more possibilities of obtaining benefits from AM inoculation (Robertson et al, 1988; Chavez and Ferrara-Cerrato, 1990; Niemi and Vestberg, 1992; Vestberg, 1992).

At the Laukaa Research and Elite Plant Unit of the Agricultural Research Centre of Finland, strawberry microplants inoculated with AM fungi at the beginning of the weaning stage have shown high growth responses in a number of experiments of different types (Vestberg, unpublished observations). Based on this experience, a 
field experiment was begun in 1990, the objective of which was to observe how such AMinoculated microplants manage after outplanting in the field and how they are affected by overwintering. Eight Finnish isolates of Glomus, screened for use with strawberry, were used together with one isolate of Glomus from Rothamsted Experimental Station, UK.

\section{MATERIALS AND METHODS}

At the beginning of the weaning stage (May 1990), micropropagated plantlets of strawberry (Fragaria $x$ ananassa Duch cv Senga Sengana were transplanted into Vefi pots $(0.25 \mathrm{I})$ containing sterilized sand fertilized with bone meal. The inocula of different fungal isolates were placed at the bottom of the planting hole before transplanting. The AM treatments were: 1) none; 2) $G$ mosseae Rothamsted; 3) $G \mathrm{sp} V_{3}$ Finland; 4) $G \operatorname{sp} V_{4}$ Finland; 5) $G$ intraradix $V_{50 / 87}$ Finland; 6) $G$ sp $V_{21 / 88}$ Finland; 7) $G$ mosseae $V_{11 b}$ Finland; 8) $G$ intraradix $V_{18}$ Finland; 9) $G$ intraradix $V_{20}$ Finland; and $10 \mathrm{G}$ intraradix $V_{31}$ Finland. Plants were grown in a greenhouse.

Eight wk later plants were outplanted into a field (silty soil), prepared for strawberry production by addition of light Sphagnum peat and lime (6 tons/ha) to give a final $\mathrm{pH}$ of 6.0. No additional inoculation was performed and fertilization was as for commercial strawberry fields. The amount of fertilizers $(300 \mathrm{~kg} / \mathrm{ha}$ $7 \mathrm{~N}: 5 \mathrm{P}: 15 \mathrm{~K}$, Kemira; and $400 \mathrm{~kg} / \mathrm{ha} 0 \mathrm{~N}: 10 \mathrm{P}: 18 \mathrm{~K}$, Kemira) was calculated on the basis of soil analysis. The strawberries were planted in 10 replicates on top of small ridges covered by black plastic. The distance between ridges was $2 \mathrm{~m}$ and between plants $33 \mathrm{~cm}$.
In mid-September of 1990 and 1991, 1 plant per treatment and per replicate was removed for assessment of shoot dry weight and runner growth, and of root colonization by the gridline intersect method (Giovannetti and Mosse, 1980). Plants removed from the experiment were replaced by new plants to fill the gaps.

Experimental data were statistically analyzed by 1 -way analysis of variance; treatment means were separated by Duncan's multiple range test.

\section{RESULTS}

At the end of the weaning stage, strawberry roots were colonized by different $A M$ isolates from 0-60\% (table I). $G$ mosseae Rothamsted, $G$ sp $V_{3}, G$ sp $V_{4}$ and $G$ intraradix $V_{18}$ all caused high infection $(50-60 \%)$. Three isolates, ie $G$ mosseae $V_{11 b}$, $G$ intraradix $V_{20}$ and $V_{31}$ resulted in infection levels close to zero. At the end of the 1990 growing season, plants collected from the field experiment still showed $50 \%$ root colonization after inoculation with $G s p V_{4}$ at the weaning stage, while those inoculated with $G$ mosseae Rothamsted showed only $1 \%$ colonization. At this stage, $G$ intraradix $V_{20}$-inoculated plants had increased their infection rate from $1-16 \%$ as compared with the weaning stage. After overwintering, in 1991, root colonization of the inoculated strawberries varied from $8-35 \%$ as compared to $4 \%$ for uninoculated plants. Plants inoculated with $G$ intraradix, ie $V_{50 / 87 j o}, V_{20}$ and $V_{31}$ had increased colonization as compared to the previous year.

Table I. The effect of arbuscular mycorrhizal inoculation on root colonization and shoot dry weight (mother plant + runners) of strawberry at the end of the weaning stage and at the end of the 1990 and 1991 growing seasons in the field.

Treatment $\frac{\text { End of weaning }}{\operatorname{VAM}(\%) \text { Shoot dry weight }(g)} \quad \frac{\text { End of } 1990}{\operatorname{VAM}(\%) \quad \text { Shoot dry weight }(g)} \quad \frac{\text { End of } 1991}{\text { VAM (\%) Shoot dry weight }(g)}$

$\begin{array}{lrlrrrr}\text { Control } & 0 & 0.21 & 3 & 2.8 & 4 & 9.5 \\ \text { Gm Roth } & 50 & 0.70^{*} & 1 & 12.5^{\star} & 12 & 17.1^{\star} \\ V_{3} & 44 & 0.51 & 15 & 10.4^{*} & 22 & 14.0 \\ V_{4} & 60 & 0.38 & 50 & 6.1^{*} & 35 & 16.3^{*} \\ V_{50 / 87 j o} & 10 & 0.32 & 12 & 5.6^{*} & 23 & 11.9 \\ V_{2188} & 12 & 0.30 & 22 & 6.4^{*} & 10 & 13.0 \\ V_{11 b} & 0 & 0.22 & 9 & 6.1^{*} & 13 & 12.9 \\ V_{18} & 50 & 0.37 & 4 & 7.8^{*} & 8 & 13.6 \\ V_{20} & 1 & 0.42 & 16 & 5.6 & 33 & 13.0 \\ V_{31} & 1 & 0.30 & 4 & 4.6 & 18 & 9.5\end{array}$


$G$ mosseae Rothamsted caused the highest growth increase in strawberry at the weaning stage (table I). This significant growth response persisted throughout the first and the second years in the field. The Finnish isolate $V_{3}$ also increased growth significantly during weaning. During the 1st $y r$ in the field, the effect of inoculation performed at the weaning stage was pronounced, and $G$ mosseae Rothamsted as well as all the Finnish isolates except $V_{20}$ and $V_{31}$ gave rise to significant growth increases. After overwintering, in 1991, however, only G mosseae Rothamsted and $G$ sp $V_{3}$ caused significant growth responses.

The fungi which promoted the greatest growth increases in shoot growth ( $G$ mosseae Rothamsted, $V_{3}, V_{4}$ and $V_{18}$ ), also caused the greatest increase in runner production at the end of the 1990 growing season (results not presented). In 1991, however, no significant differences in runner production were observed between uninoculated and inoculated strawberries.

\section{DISCUSSION AND CONCLUSION}

Micropropagated strawberry benefits from AM inoculation (Kiernan et al, 1984; Robertson et al, 1988), a fact which was also observed in this investigation. The growth increasing effect of the most efficient isolates persisted throughout the 1 st $\mathrm{yr}$ in the field and even after overwintering in the 2nd yr. This suggests that the introduced strains which were highly efficient were able to compete with the indigenous strains and were not destroyed during the winter. The influence of winter on the management of introduced AM fungi in roots of strawberry warrants detailed studies, in which development of both the AM fungi and roots should be considered.

Inoculation also positively influenced runner development. There was, however, no indication of the phenomenon observed by Hrselova et al (1989), according to whom inoculation can decrease the shoot dry weight of the mother plant and at the same time strongly increase runner plant production.

Strawberry is the most important small fruit plant in Finland. Approximately $80 \%$ of the strawberry plants sold originate from micropropagated elite plants. From this point of view, successful inoculation of strawberries at the beginning of the weaning stage may have a potential as a useful technique even in commercial strawberry production. The benefits of inoculation at the weaning stage could possibly be improved further by modifying growth substrata and using slow release fertilizers (Williams et al, 1992).

\section{REFERENCES}

Chavez MG, Ferrara-Cerrato R (1990) Effect of vesicular-arbuscular mycorrhizae on tissue culturederived plantlets of strawberry. HortSci 25, 903905

Daft MJ, Okusanya BO (1973) Effect of Endogone mycorrhiza on plant growth. VI. Influence of infection on the anatomy and reproductive development in four hosts. New Phytol 72, 1333-1339

Dunne MJ, Fitter AH (1989) The phosphorus budget of field-grown strawberry (Fragaria $x$ ananassa cv Hapil) crop: evidence for a mycorrhizal contribution. Ann Appl Biol 114, 185-193

Giovannetti M, Mosse B (1980) An evaluation of techniques for measuring vesicular-arbuscular mycorrhizal infection in roots. New Phytol 84, 489-500

Holevas CD (1966) The effect of vesicular-arbuscular mycorrhiza on the uptake of soil phosphorus by strawberry (Fragaria sp var Cambridge Favourite). $J$ Hortic Sci 41, 57-64

Hrselova H, Gryndler M, Vancura V (1989) Influence of inoculation with VA mycorrhizal fungus Glomus $\mathrm{sp}$ on the growth of strawberry and runner formation. Agric Ecosyst Environ 29, 193-197

Kiernan JM, Hendrix JM, Stoltz LP, Maronek DM (1984) Characterization of strawberry plants produced by tissue culture and infected with specific mycorrhizal fungi. HortSci 19, 83-885

Niemi M, Vestberg M (1992) Inoculation of commercially grown strawberry with VA mycorrhizal fungi. Plant Soil 95, 133-142

Robertson WJ, Boyle CD, Brown HL (1988) Endomycorrhizal status of certified strawberry nursery stock. J Am Soc Hortic Sci 113, 525-529

Vestberg $M$ (1992) The effect of growth substrate and fertilizer on the growth and vesicular-arbuscular mycorrhizal infection of three hosts. Agric Sci Finl 1, 95-105

Williams SCK, Vestberg M, Uosukainen M, Dodd JC, Jeffries $P$ (1992) Effects of fertilizers and arbuscular mycorrhizal fungi on the post vitro growth of micropropagated strawberry. Agronomie 12, 851-857 